\title{
Length and Weight Relationships for 31 Species of Fishes Caught by Trawl Off the Arabian Sea Coast of Oman
}

\author{
Brett A. Human* and Haithem Al-Busaidi \\ Marine Science and Fisheries Centre \\ PO Box 227, PC 100 Muscat \\ Sultanate of Oman \\ علاقات الطول والوزن لإحدى وثلاثون نوعا من الأسماك المصطادة بطريقة الجرف من

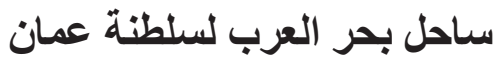

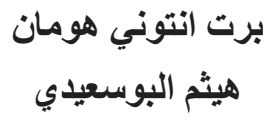

الخلاصة: جمعت قياسات الطول و الوزن لإحدى وثلاثون نوعا من الأسماك التي صادف صيدها في بحر العرب لساحل عمان

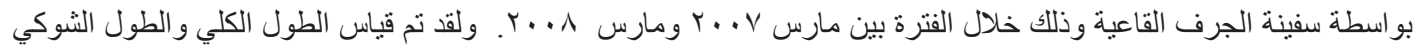

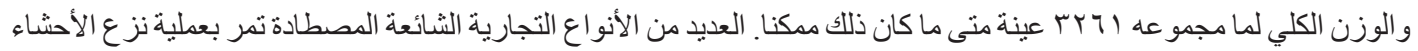

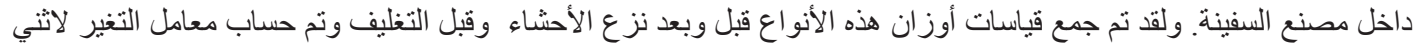

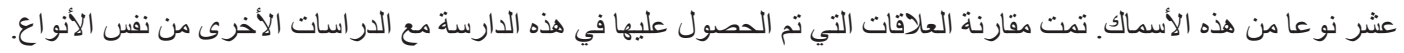

ABSTRACT: Lengt h and weight mea sur ement for $31 \mathrm{fish}$ species encount er ed in the Ar a bia $\mathrm{n}$ Sea, off $\mathrm{t}$ he Oma $\mathrm{n}$ Coast, were collected by demersal trawling during March 2007 and March 2008. A total of 3,261 specimens were measured for total length, or fork length, where appropriate, and green weight. Several commonly caught commercial species undergo onboard processing (dressing) prior to packaging, and dressed weight to green weight regressions and conversion factors were calculated for 12 of these species. The relationships obtained in this study were compared with those of other studies for the same fish species. These data are fundamental to understanding the biological parameters of fishes, and can be applied to fisheries stock assessment and management models.

Keywords: Demersal trawling, Arabian Sea, length-weight relationships.

\section{Introduction}

An industrial demersal trawl fishery exists off the coast of the Sultanate of Oman, operating between north of Masirah Island to the Al-Hallaniyat Islands in the Arabian Sea, in depths between 50 to $150 \mathrm{~m}$ (Fig. 1). This fishery was initiated by the government of the Sultanate of Oman in the late 1970's to develop an alternative economy to petroleum products (Johannesson, 1991).

In 1986, seven foreign trawlers and two Omani vessels were operating in the Oman demersal trawl fishery (McClure, 1987). By 2003, the number of industrial vessels trawling in the Oman demersal trawl zone had expanded to 20, all of which were foreign (Anon., 2004). Reported landings peaked in 1997 at 34,549 $\mathrm{mt}$ (accounting for $29 \%$ of the total Oman landings for that year), and landings for 2003 were reported to be $19,608 \mathrm{mt}$ (14\% of the total Oman landings).

Human (2007) reported the species composition and quantum of fishes caught during a brief survey of the demersal fishing area. The Marine Science and 


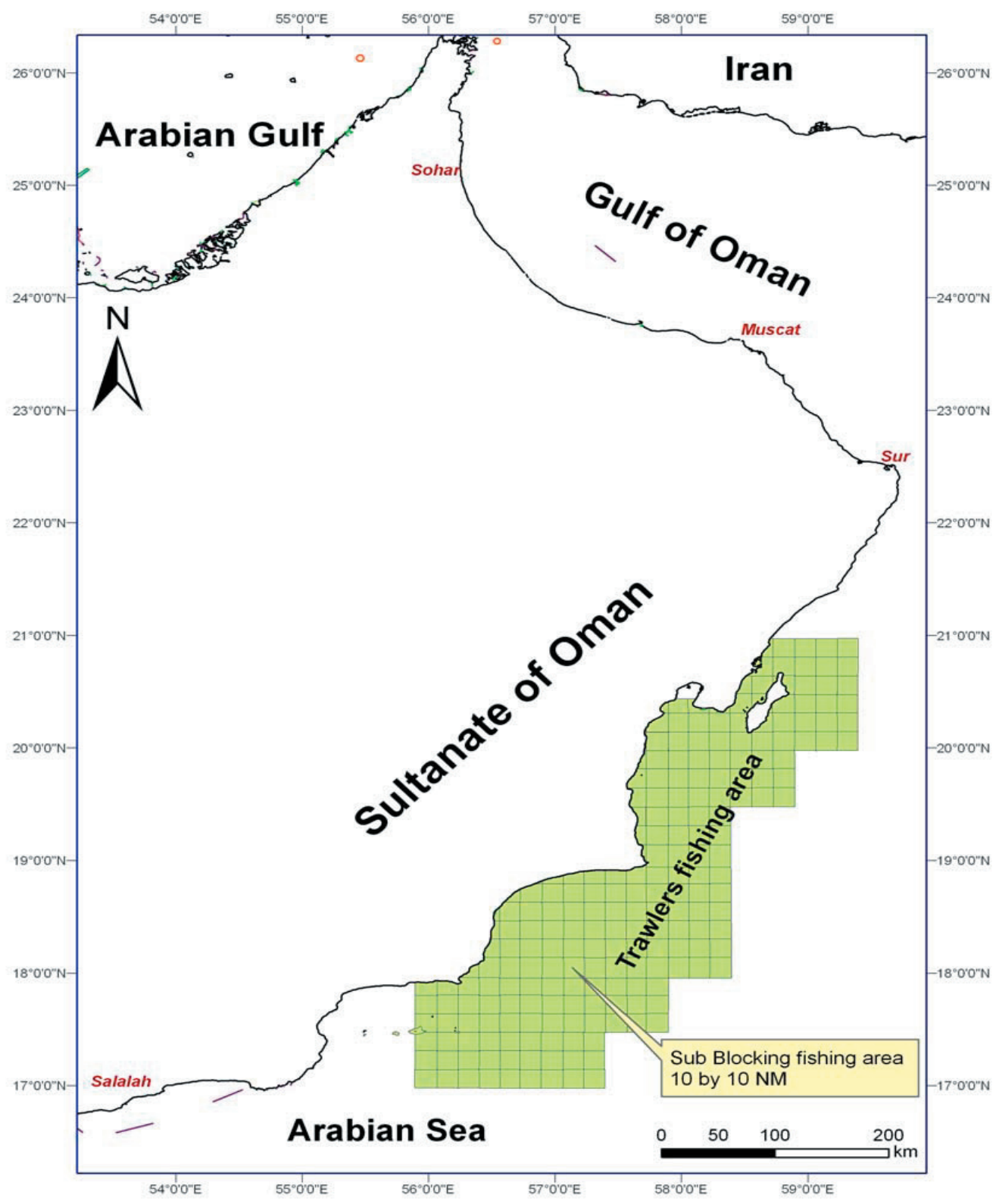

Figure 1. Chart of the Sultanae of Oman showing the demersal trawl fishery zone (Lubna Al-Kharusi). 
Fisheries Centre is currently undertaking a project to investigate the biology, and assess the stocks of 13 species of commercially important demersal fishes (see Al-Nahdi et al., 200x; Al-Waeli et al., 200xa; and Al-Waeli et al., 200xb in this issue). In addition to this, the Ministry of Fisheries Wealth is currently conducting a 15-month project, the Fish Resources Assessment Survey of the Arabian Sea Coast of Oman, to estimate the current biomass of the fisheries resources in the Arabian Sea, off the Oman coast. This survey is due to be completed in September 2008.

The last survey and assessment of this fishery was by the R.V. Rastrelliger from late 1989 to late 1990 (Johannesson, 1991), some 17 years ago. In that study, the demersal stock of the entire Omani coastline, from the Musandam Peninsula to Salalah was assessed. The only other major fisheries resources assessment conducted along the Omani coastline was by the R.V. Dr. Fridtjof Nansen, which conducted demersal biomass estimates using acoustic methods in 1983 and 1984 (Strømme, 1986). A small scale fisheries resources assessment was conducted in the Arabian Gulf and the northern Gulf of Oman during 2003-2004 (Valinassab et al., 2006). These studies did not provide length or weight relationships.

Length and weight relationships are basic, yet represent fundamental data that are essential to understanding the biological parameters of fishes, which can then be applied to fisheries stock assessment and management (Gonzales et al., 2000; Muto et al., 2000; Morato et al., 2001; Can et al., 2002; Wigley et al., 2003; Abdurahiman et al., 2004; and Frota et al., 2004). This study provides length and weight relationships for 31 fish species encountered during a recent survey of the Oman demersal fishing zone. Additionally, most of the more commonly caught, commercially important species undergo processing (dressing) prior to packaging. Landings of these species are reported in dressed weight, therefore it is essential to know the dressed weight to green weight (total wet weight) conversion factors to convert landed weight into total weight for fisheries modelling and management purposes.

\section{Materials and Methods}

The area demarcated for demersal trawling within the Sultanate of Oman is south of $21^{\circ} \mathrm{N}$, north of $17^{\circ} \mathrm{N}$, in water not less than $50 \mathrm{~m}$ deep, or not closer than $10 \mathrm{~nm}$ to the coast, in the Arabian Sea within the Omani EEZ
(Fig. 1). Sampling was conducted in this area from $5^{\text {th }}$ March - 24 $4^{\text {th }}$ March, 2007, during commercial fishing operations (bottom trawling). Between $27^{\text {th }}$ February - $18^{\text {th }}$ March, 2008, fishes were sampled from the demersal trawl zone, and areas of the Arabian Sea, in a depth range between 20-200m, extending south of the demersal trawl zone to the Yemen border, during part of the third cruise of the Fish Resources Assessment Survey of the Arabian Sea Coast of Oman.

The F.V. Al-Mustaqila I, a factory stern trawler with a gross tonnage of 1226 tonnes and overall length (L.O.A) of $45.2 \mathrm{~m}$ (Chris Carey, personal communication), was used as a sampling platform. A trawl net of multiple mesh sizes $(110 \mathrm{~mm}$ in the cod-end), a ground rope of $100 \mathrm{~m}$, and a door spread whilst trawling approximately $100 \mathrm{~m}$ wide at $100 \mathrm{~m}$ depth was used during commercial fishing operations. The wingtip spread was approximately $35 \mathrm{~m}$, and the opening of the mouth of the trawl was between 5.5$6 \mathrm{~m}$ (monitored by sensors on the headline). The trawl warps used were $32 \mathrm{~mm}$ dyform warps. The trawling speed was approximately 4 knots.

The same vessel is being used for the Fish Resources Assessment Survey of the Arabian Sea Coast of Oman. The trawl warps are the same, however the bottom trawl gear is different to that used for commercial fishing. For that survey, a trawl net of multiple sizes with a cod-end mesh size of $40 \mathrm{~mm}$, a ground rope of $100 \mathrm{~m}$, and a door spread whilst trawling approximately $100 \mathrm{~m}$ wide at $100 \mathrm{~m}$ depth was used during commercial fishing operations. The wingtip spread was approximately $35 \mathrm{~m}$, and the opening of the mouth of the trawl was between $5.5-6 \mathrm{~m}$ (monitored by sensors on the headline). The trawling speed was approximately 3.5 knots (Neil Bagley, personal communication).

Fishes were collected and sorted inside the onboard fish processing factory. Species were identified using Smith \& Heemstra (1986), AlAbdessalaam (1995), Randall (1995), or Carpenter et al. (1997). All length and weight measurements were taken on freshly captured fishes. During commercial fishing, fish were measured on a measuring board, and the same balance was used for the entire cruise. For fish measured during the Fish Resources Assessment Survey of the Arabian Sea Coast of Oman, data were captured directly onto a NIWA (National Institute of Water and Atmospheric Research Ltd., New Zealand) computer controlled digitising work station. These 
data have been incorporated into the total database for that survey.

Linear measurements were taken in a straight line and did not follow the natural curves of the animal (see Compagno, 2001; and Human, 2006). Total length (TL) was the greatest straight line measurement from the anterior tip of the snout to the posterior tip of the caudal fin, with the caudal fin lying straight and not in its natural position, and was applied to fishes lacking a forked tail and sharks. Fork length (FL) was the straight line measurement from the anterior tip of the snout to the anterior margin of the fork in the caudal fin, in fish with a forked caudal fin. All length measurements were taken to the nearest $5 \mathrm{~mm}$, and all weight measurements to the nearest $5 \mathrm{~g}$ during commercial fishing, whereas, all length measurements were taken to the nearest $1 \mathrm{~mm}$, and all weight measurements to the nearest $1 \mathrm{~g}$ during the Fish Resources Assessment Survey of the Arabian Sea Coast of Oman.

To determine dressed weight to green weight conversion factors, fish were sorted by species into bins (typically 4-10kg per bin, consisting of 1 to 6 specimens depending on size) and weighed for green weight $(\mathrm{GW})$. The bin was then given to factory workers who processed the fish. The processing of bony fishes involved removal of the head, tail, and entrails; while processing of sharks involved removal of the head, fins, tail, entrails, and a section of the abdomen from the insertion of the pelvic fin to the insertion of the pectoral fins. The fish were then placed back into the bin and reweighed for dressed weight (DW).

Regressions were performed on length-weight relationships. In all length-weight regressions, the data were fitted with either power or exponential curves, depending on which type of curve provided the best fit based on least squares. All GW-DW relationships were linearly regressed, and conversion factors were determined for the latter.

\section{Results and Discussion}

A systematic list of the species reported in this study is given in Table 1, which also lists the family to which the species belong, and the English common name. Due to space constraints, graphs of all of the regressions will not be presented here. The length and weight regressions are tabulated as follows: TL-GW (11 species; $\mathrm{n}=1194$; Table 2); FL-GW (20 species; $\mathrm{n}=$ 1904; Table 3); and GW-DW (9 species; $n=163$ ) with gross conversion factors for converting DW to GW, and vice versa, given in Table 4 .

It was possible to compare only a few species presented here to studies that had been conducted previously. Of the literature examined for this study, all presented length-weight relationships as a power curve, or an alogarithmic transformation thereof, in the form:

$$
\mathrm{Wt}=\mathrm{a} \cdot \mathrm{L}^{\mathrm{b}}
$$

where $\mathrm{Wt}$ is weight, $\mathrm{L}$ is length, $\mathrm{a}$ is a scaling constant, and $\mathrm{b}$ is an allometric growth coefficient.

The allometric growth coefficient from equation (1) has been used as an indicator of a wide range of biological parameters, including - rate of weight gain relative to growth in length, rate of gonad development, rate of feeding, growth rate, ontogenetic change, sexual dimorphism, maturity, age structure, and condition; as well as a predictor of weight at age; for biomass estimation and stock assessment purposes (Morato et al., 2001; Can et al., 2002; Abdurahiman et al., 2004; and Frota et al., 2004). However, it has been noted that the allometric growth coefficient is highly variable due to factors such as inter- and intrapopulation differences, gender, seasonality, annual variability, food availability (quantity and quality), reproductive state, migratory activities, temperature, salinity, as well as sampling biases such as length range of the sample population due to gear selectivity (Muto et al., 2000; Morato et al., 2001; Can et al., 2002; Frota et al., 2004; Akyol et al., 2007; and see Wigley et al. (2003) for a comparison of the effects of season, gender and length range, within an area).

Most of the literature examined for this study gave ranges and statistical significance values for allometric growth coefficients, however, given the variability and number of factors that influence the allometric growth coefficient, it is very difficult to assign true biological meaning to this coefficient (see Frota et al., 2004). The allometric growth coefficient can best be considered as a general indicator of the condition (ie. weight of the fish relative to length) of a fish species within restricted temporal and spatial limits. Additionally, this study found that exponential curves provided a better description of length-weight data for some species, and the type of length measurement used, compared to power curve regressions, indicated by higher $\mathrm{R}^{2}$ values (data not shown). 
Table 1. Systematic listing of fish species, including family and English common name, for which length-weight relationships are reported in this study.

\begin{tabular}{lll}
\hline Family & Species & Common Name \\
\hline Carcharhinidae & Rhizoprionodon acutus & Milk shark \\
Muraenesocidae & Muraenesox cinereus & Daggertooth pike conger \\
Clupeidae & Dussumieria elopsoides & Slender rainbow sardine \\
Ariidae & Arius bilineatus & Roundsnout sea catfish \\
Ariidae & Arius dussumieri & Blacktip sea catfish \\
Synodontidae & Saurida undosquamis & Brushtooth lizardfish \\
Synodontidae & Synodus dermatogenys & Clearfin lizardfish \\
Synodontidae & Trachinocephalus myops & Snakefish \\
Triglidae & Lepidotrigla bispinosa & Bullhorn gurnard \\
Platycephalidae & Kumococius rodericensis & Spiny flathead \\
Carangidae & Alectis indicus & Indian threadfish \\
Carangidae & Carangoides chrysophrys & Longnose jack \\
Carangidae & Decapterus russelli & Indian scad \\
Carangidae & Seriola rivoliana & Almaco jack \\
Haemulidae & Pomadasys commersonnii & Spotted grunt \\
Nemipteridae & Nemipterus randalli & Randalls threadfin bream \\
Lethrinidae & Lethrinus nebulosus & Spangled emporer \\
Sparidae & Argyrops spinifer & King soldierbream \\
Sparidae & Cheimerius nufar & Santer seabream \\
Sparidae & Pagellus affinis & Arabian pandora \\
Sciaenidae & Argyrosomus hololepidotus & Southern meagre \\
Pinguipedidae & Parapercis alboguttata & Bluenose sandperch \\
Paralichthyidae & Psuedorhombus arsius & Largetooth flounder \\
Trichiuridae & Trichiurus lepturus & Largehead cutlassfish \\
Scombridae & Sarda orientalis & Striped bonito \\
Scombridae & Scomber japonicus & Chub mackerel \\
Drepanidae & Drepane longimana & Barred sicklefish \\
Balistidae & Sufflamen fraenatus & Bridled triggerfish \\
Ostraciidae & Tetrosomus gibbosus & Thornback trunkfish \\
Tetraodontidae & Lagocephalus guentheri & Diamondback pufferfish \\
Diodontidae & Cyclichthys spilostylus & Yellowspotted burrfish \\
\hline & & \\
& &
\end{tabular}

\section{Synodontidae}

The brushtooth lizardfish appears to be a common bycatch species both in the Arabian Sea, and in the eastern Mediterranean Sea. Abdallah (2002) reported the length-weight relationship for the brushtooth lizardfish as $\mathrm{Wt}=0.003 \mathrm{TL}^{3.30}\left(\mathrm{R}^{2}=0.953 ; \mathrm{N}=465\right)$ from the trawl fishing ground off Alexandria, Egypt, while Can et al. (2002) reported $\mathrm{Wt}=0.0117 \mathrm{TL}^{2.7971}$ $\left(\mathrm{R}^{2}=0.90 ; \mathrm{N}=100\right)$, and Akyol et al. $(2007)$ reported $\mathrm{Wt}=0.0046 \mathrm{TL}^{3.109}\left(\mathrm{R}^{2}=0.951 ; \mathrm{N}=80\right)$, from Turkish waters in the Aegean Sea. Abdurahiman et al. (2004) reported $\mathrm{Wt}=1.34 \times 10^{-6} \mathrm{TL}^{3.306}\left(\mathrm{R}^{2}=0.99 ; \mathrm{N}=2774\right)$ from Karnataka, India, Arabian Sea. Fork length was measured for this species in the current study (Table 3 ), therefore, while it is not possible to make a direct comparison between this study and other studies, the allometric growth coefficients between studies are equivalent for this species from different geographic locations and different time periods, suggesting that the brushtooth lizardfish has consistent growth parameters over time and space.

Frota et al. (2004) reported the length-weight relationship for snakefish off Brazil as $\mathrm{Wt}=7 \times 10^{-}$ ${ }^{4} \mathrm{FL}^{3.881}\left(\mathrm{R}^{2}=.976 ; \mathrm{N}=21\right)$. The lower values for both the scaling constant and the allometric growth 
Table 2. Summary of the regression of total length (TL) against green weight (Wt), including species common name, sample size, regression equation, $\mathrm{R}^{2}$ value, and size range, for 11 species of fishes caught using demersal trawl gear off Oman. Length is in millimetres and weight is in grams.

\begin{tabular}{lrllr}
\hline Common Name & N & Regression & $\mathbf{R}^{2}$ & TL Size Range \\
\hline Arabian pandora & 68 & $W t=2 \times 10^{-5} T L^{2.9424}$ & 0.9811 & $100-425$ \\
Barred sicklefish & 157 & $W t=2 \times 10^{-5} T L^{3.0841}$ & 0.9176 & $257-419$ \\
Bridled triggerfish & 117 & $W t=2 \times 10^{-5} T L^{3.0406}$ & 0.9926 & $130-355$ \\
Chub mackerel & 112 & $W t=3 \times 10^{-6} T L^{3.195}$ & 0.9526 & $210-390$ \\
Daggertooth pike conger & 35 & $W t=33 \times 861 e^{0.0037 T L}$ & 0.7541 & $700-1040$ \\
King soldier bream & 85 & $W t=3 \times 10^{-5} T L^{2.8572}$ & 0.9707 & $250-640$ \\
Largehead cutlassfish & 390 & $W t=2 \times 10^{-7} T L^{3.2066}$ & 0.8551 & $675-1210$ \\
Largetooth flounder & 74 & $W t=4 \times 10^{-6} T L^{3.1671}$ & 0.9945 & $82-391$ \\
Striped bonito & 51 & $W t=8 \times 10^{-6} T L^{3.0324}$ & 0.9723 & $400-655$ \\
Thornback trunkfish & 71 & $W t=16.885 e^{0.0132 T L}$ & 0.8629 & $158-250$ \\
Yellowspotted burrfish & 34 & $W t=7 \times 10^{-4} T L^{2.4868}$ & 0.9225 & $191-391$ \\
\hline
\end{tabular}

Table 3. Summary of the regression of fork length (FL) against green weight (Wt), including species common name, sample size, regression equation, $\mathrm{R}^{2}$ value, and size range, for 20 species of fishes caught using demersal trawl gear off Oman. Length is in millimetres and weight is in grams.

\begin{tabular}{lrllr}
\hline Common Name & N & Regression & R $^{2}$ & FL Size Range \\
\hline Arabian pandora & 68 & $W t=4 \times 10^{-5} F L^{2.8851}$ & 0.984 & $90-385$ \\
Blacktip sea catfish & 79 & $W t=134.4 e^{0.0053 F L}$ & 0.876 & $330-630$ \\
Bluenose sandperch & 65 & $W t=4 \times 10^{-6} F L^{3.1647}$ & 0.9586 & $72-180$ \\
Brushtooth lizardfish & 200 & $W t=3 \times 10^{-6} F L^{3.2185}$ & 0.9889 & $60-319$ \\
Bullhorn gurnard & 167 & $W t=6 \times 10^{0-5} F L^{2.6944}$ & 0.9888 & $45-217$ \\
Chub mackerel & 112 & $W t=5 \times 10^{-6} F L^{3.1769}$ & 0.9583 & $190-350$ \\
Clearfin lizardfish & 91 & $W t=0.3791 e^{-0.0318 F L}$ & 0.8772 & $80-141$ \\
Diamondback pufferfish & 35 & $W t=2 \times 10^{-5} F L^{3.0134}$ & 0.9837 & $74-440$ \\
Indian scad & 83 & $W t=5 \times 10^{-6} F L^{3.1762}$ & 0.9694 & $75-217$ \\
King soldier bream & 85 & $W t=6 \times 10^{-5} F L^{2.8206}$ & 0.9738 & $215-575$ \\
Longnose jack & 89 & $W t=8 \times 10^{-5} F L^{2.7666}$ & 0.9827 & $233-660$ \\
Randalls threadfin bream & 98 & $W t=0.6977 e^{0.03 F L}$ & 0.9479 & $70-129$ \\
Roundsnout sea catfish & 180 & $W t=1 \times 10^{-5} F L^{3.0973}$ & 0.9784 & $222-447$ \\
Santer seabream & 145 & $W t=3 \times 10^{-5} F L^{2.9356}$ & 0.994 & $104-575$ \\
Slender rainbow sardine & 35 & $W t=3.6748 e^{0.0157 F L}$ & 0.7682 & $155-196$ \\
Snakefish & 82 & $W t=9 \times 10^{-7} F L^{3.5225}$ & 0.9149 & $76-154$ \\
Spangled emporer & 136 & $W t=2 \times 10^{-5} F L^{2.9998}$ & 0.9949 & $239-603$ \\
Spiny flathead & 40 & $W t=1 \times 10^{-5} F L^{2.9576}$ & 0.978 & $72-271$ \\
Spotted grunt & 63 & $W t=2 \times 10^{-3} F L^{2.2189}$ & 0.6665 & $589-715$ \\
Striped bonito & 51 & $W t=4 \times 10^{-6} F L^{3.2119}$ & 0.9779 & $365-580$ \\
\hline
\end{tabular}




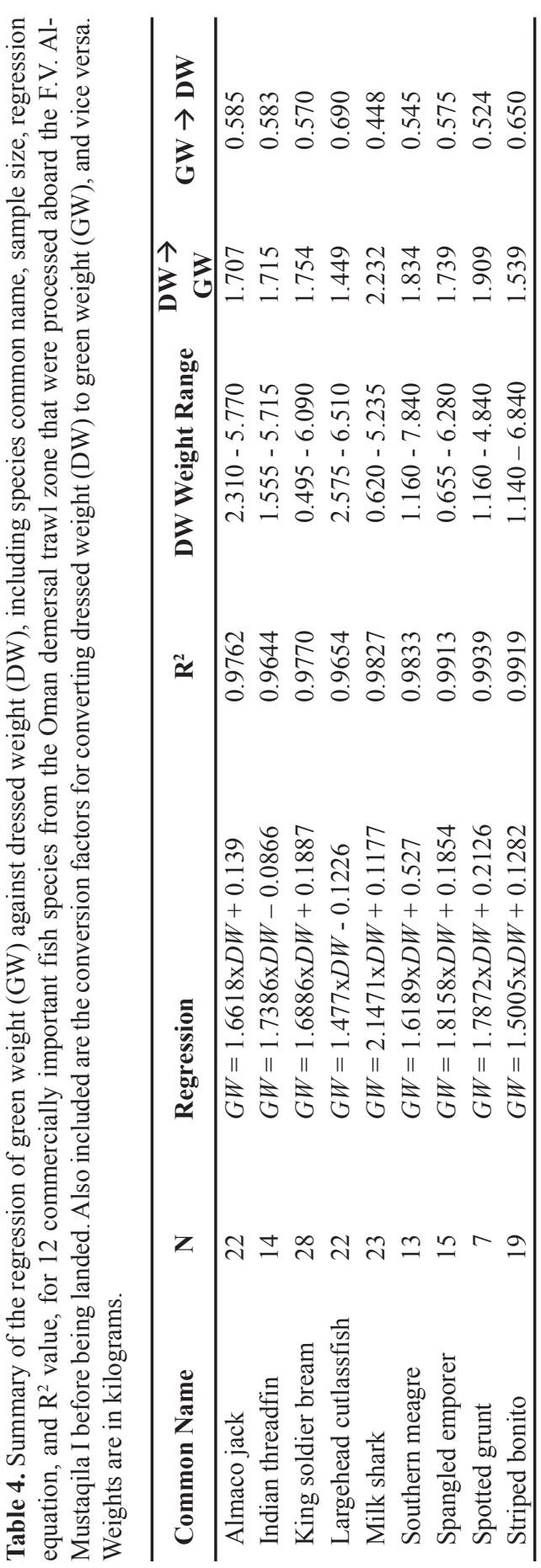

coefficient obtained in this study (Table 3) indicate that snakefish have a poorer general condition in the Arabian Sea off Oman compared to that off Brazil at the time of that study.

\section{Carangidae}

Abdurahim et al. (2004) provided a length-weight relationship of $\mathrm{Wt}=0.073 \mathrm{TL}^{2.306}$ for male Indian scad $\left(\mathrm{R}^{2}=0.86 ; \mathrm{N}=199\right)$, and $\mathrm{Wt}=0.024 \mathrm{TL}^{2.647}$ for female Indian scad $\left(\mathrm{R}^{2}=0.93 ; \mathrm{N}=150\right)$, from off India. The scaling constant was found to be much lower, and the allometric growth coefficient much higher in the current study (Table 3) compared to that of Abdurahim et al. (2004), and although fork length was used in the current study compared to total length used by Abdurahim et al., it is unlikely that this difference alone accounts for the differences in parameters, and may indicate that Indian scad in the Arabian Sea measured during this study are of better general condition than those of India at the time of Abdurahim et al.'s study.

\section{Lethrinidae}

Spangled emporer was studied from all coastal waters off Oman by Al-Mamry (2006) who reported for males a length-weight relationship of $\mathrm{Wt}=2 \times 10^{-5} \mathrm{TL}^{2.859}\left(\mathrm{R}^{2}\right.$ $=0.976 ; \mathrm{N}=502)$; females $\mathrm{Wt}=2 \times 10^{-5} \mathrm{TL}^{2.856}\left(\mathrm{R}^{2}\right.$ $=0.971 ; \mathrm{N}=779)$; and sexes combined $\mathrm{Wt}=2 \times 10^{-}$ ${ }^{5} \mathrm{TL}^{2.847}\left(\mathrm{R}^{2}=0.973 ; \mathrm{N}=1281\right)$. The length-weight relationships for this species restricted to the Arabian Sea off Oman (McIlwain et al., 2006) are males Wt $=5.21 \times 10^{-2} \mathrm{FL}^{2.732}\left(\mathrm{R}^{2}=0.94 ; \mathrm{N}=407\right)$; females $\mathrm{Wt}$ $=3.09 \times 10^{-2} \mathrm{FL}^{2.867}\left(\mathrm{R}^{2}=0.98 ; \mathrm{N}=377\right)$; and sexes combined $\mathrm{Wt}=3.43 \times 10^{-2} \mathrm{TL}^{2.839}\left(\mathrm{R}^{2}=0.97 ; \mathrm{N}=784\right)$. The results obtained in the current study (Table 3 ) are similar to those studies above, indicating that the general condition of spangled emporer off Oman has remained constant.

\section{Sparidae}

Weight-length relationships for Arabian pandora of $\mathrm{Wt}=2.38 \times 10^{-2} \mathrm{FL}^{2.975}$ (males; $\left.\mathrm{R}^{2}=0.95 ; \mathrm{N}=718\right), \mathrm{Wt}$ $=2.39 \times 10^{-2} \mathrm{FL}^{2.973}$ (females; $\mathrm{R}^{2}=0.92 ; \mathrm{N}=630$ ), and $\mathrm{Wt}=2.38 \times 10^{-2} \mathrm{FL}^{2.974}\left(\right.$ sexes combined; $\mathrm{R}^{2}=0.94 ; \mathrm{N}=$ 1348) were provided by McIlwain et al. (2006) from the Arabian Sea of Oman. Both the scaling constant and the allometric growth coefficient were found to be lower in the current study (Table 3), indicating that the general condition of Arabian pandora in the Arabian 
Sea off Oman had decreased slightly during the time interval between the two studies.

Al-Mamry (2006) reported length-weight relationships for king soldier bream of $\mathrm{Wt}=5 \times 10^{-}$ ${ }^{5} \mathrm{TL}^{2.692}\left(\mathrm{R}^{2}=0.968 ; \mathrm{N}=398\right)$ for males, $\mathrm{Wt}=6 \times 10^{-}$ ${ }^{5} \mathrm{TL}^{2.642}\left(\mathrm{R}^{2}=0.976 ; \mathrm{N}=347\right)$ for females, and $\mathrm{Wt}$ $=6 \times 10^{-5} \mathrm{TL}^{2.666}\left(\mathrm{R}^{2}=0.977 ; \mathrm{N}=745\right)$ for sexes combined, from all coastal waters of Oman. McIlwain et al. (2006) studied king soldier bream captured off Oman in the Arabian Sea only, and found the following weight-length relationships for that species: $\mathrm{Wt}=8.86 \times 10^{-2} \mathrm{FL}^{2.626}\left(\mathrm{R}^{2}=0.97 ; \mathrm{N}=492\right)$ for males, $\mathrm{Wt}=8.42 \times 10^{-2} \mathrm{FL}^{2.64}\left(\mathrm{R}^{2}=0.98 ; \mathrm{N}=438\right)$ for females, and $\mathrm{Wt}=8.6 \times 10^{-2} \mathrm{FL}^{2.635}\left(\mathrm{R}^{2}=0.98 ; \mathrm{N}=930\right)$ for sexes combined. These values were slightly smaller than that reported here (Table 3), which may indicate that the condition of the fish have improved slightly during the period between the two studies.

Santer seabream were studied from the Arabian Sea off Oman by McIlwain et al. (2006), and gave length-weight relationships for males $\mathrm{Wt}=3.15 \times 10^{-}$ ${ }^{2} \mathrm{FL}^{2.872}\left(\mathrm{R}^{2}=0.99 ; \mathrm{N}=458\right)$, females $\mathrm{Wt}=3.38 \times 10$ ${ }^{2} \mathrm{FL}^{2.849}\left(\mathrm{R}^{2}=0.98 ; \mathrm{N}=499\right)$, and for sexes combined $\mathrm{Wt}=3.12 \times 10^{-2} \mathrm{FL}^{2.875}\left(\mathrm{R}^{2}=0.98 ; \mathrm{N}=957\right)$. In the current study (Table 3), the scaling constant was lower, however, the allometric growth coefficient was higher, indicating that growth rate may have increased at the cost of general condition and may reflect the impact of heavy fisheries pressure on this species in this area.

\section{Paralichthyidae}

Weight-length relationships for largetooth flounder from off of India were given for males $\mathrm{Wt}=4 \times 10^{-}$ ${ }^{3} \mathrm{TL}^{3.256}\left(\mathrm{R}^{2}=0.98 ; \mathrm{N}=147\right)$, and females $\mathrm{Wt}=$ $3 \times 10^{-3} \mathrm{TL}^{3.378}\left(\mathrm{R}^{2}=0.99 ; \mathrm{N}=160\right)$ by Abdurahiman et al. (2004). These values indicate that the general condition of largetooth flounder was better off India at that time period than off Oman in the Arabian Sea at the time of this study (Table 3).

\section{Trichiuridae}

The largehead cutlassfish is a common catch in the Indian Ocean and the Atlantic Ocean, but most length-weight relationships come from the Atlantic Ocean. Sheridan et al. (1984) reported a lengthweight relationship of $\mathrm{Wt}=5.248 \times 10^{-8} \mathrm{TL}^{3.37}\left(\mathrm{R}^{2}\right.$ $=0.97 ; \mathrm{N}=853$ ) from the northern Gulf of Mexico, northwest Atlantic Ocean. All other reports from the Atlantic Ocean come from off the Brazilian coast in the southwest Atlantic Ocean. Bernardes \& RossiWongtschowski (2000) reported $\mathrm{Wt}=1 \times 10^{-7} \mathrm{TL}^{3.220}$ $\left(\mathrm{R}^{2}=0.986 ; \mathrm{N}=2471\right)$, while in the same year Muto et al. (2000) reported $\mathrm{Wt}=1.342 \times 10^{-7} \mathrm{TL}^{3.192}\left(\mathrm{R}^{2}=0.945\right.$; $\mathrm{N}=485$ ), from different regions of the Brazilian coast. Later, Frota et al. (2004) gave the length-weight relationship of this species using preanal length, $\mathrm{Wt}=$ $0.0338 \mathrm{LPA}^{2.653}\left(\mathrm{R}^{2}=0.966 ; \mathrm{N}=111\right)$ from Brazil. Two studies report length-weight data for this species from the Arabian Sea. Abdurahiman et al. (2004) reported for males $\mathrm{Wt}=0.001 \mathrm{TL}^{2.819}\left(\mathrm{R}^{2}=0.91 ; \mathrm{N}=200\right)$, and females $\mathrm{Wt}=0.001 \mathrm{TL}^{3.029}\left(\mathrm{R}^{2}=0.95 ; \mathrm{N}=200\right)$, from southwest India, while Al-Nahdi et al. (200x) reported for males $\mathrm{Wt}=2.67 \times 10^{-6} \mathrm{TL}^{2.803}\left(\mathrm{R}^{2}=0.91 ; \mathrm{N}=52\right)$, females $\mathrm{Wt}=6.77 \times 10^{-7} \mathrm{TL}^{3.113}\left(\mathrm{R}^{2}=0.91 ; \mathrm{N}=245\right)$, and for sexes combined $\mathrm{Wt}=1.23 \times 10^{-6} \mathrm{TL}^{2.989}\left(\mathrm{R}^{2}=0.92\right.$; $\mathrm{N}=388$ ). Both the scaling constant and the allometric growth coefficient are similar between all studies, including the current study (Table 2), indicating that the condition of fish and the growth parameters of this species are similar between the Arabian Sea and the western Atlantic.

\section{Scombridae}

The allometric growth factor reported here for chub mackerel (Table 3) is less than that reported by Santos et al. (2002) who gave a length-weight relationship of $\mathrm{Wt}=2.1 \times 10^{-3} \mathrm{TL}^{3.408}$ for this species from off of Portugal, however, this may be an artefact of the use of total length in that study, compared to the use of fork length in the current study. Although lengthweight relationships were not provided by Mallicoate \& Parrish (1981), they conducted a detailed growth analysis of this species from off California, USA, in the western Pacific.

\section{Balistidae}

Sahayak (2005) provided the length-weight relationship for bridled triggerfish from Indian seas as $\mathrm{Wt}=9.05 \times 10^{-10} \mathrm{TL}^{2.7296}\left(\mathrm{R}^{2}=0.9301 ; \mathrm{N}=514\right)$. The larger scaling constant and allometric growth coefficient indicate that this species had a better general condition at the time of this study in the Arabian Sea (Table 2), compared to off India in 2005.

\section{Conclusion}

This study provides length and weight relationships for fishes from the Arabian Sea coast of Oman using demersal trawl gear. Many weight-length relationships 
for the fishes found in the Arabian Sea off the coast of Oman are reported for the first time.

Given the intensity at which this zone is being fished (Human, 2007), as well as the fishing intensity that is occurring in other fishing sectors of Oman (Anon, 2004; and Henderson et al., 2007), it is hoped that the data presented in this study will aid in improving the management of the fisheries off the Arabian Sea coast of Oman.

\section{Acknowledgements}

The authors are indebted to all of the crew aboard the F.V. Al-Mustaqila I, particularly Nikolayevich Vyacheslav Gettun and Viktor Terentyev during the 2007 cruise. Mohamed Al-Jabri (Protein Products International) and Ernie Chadwick (previously of PPI) arranged seatime for the authors during commercial fishing operations. The authors were generously allocated hold space for storage of frozen specimens, and numerous factory workers assisted with the processing of fishes for the green weight-dressed weight comparisons.

The authors thank the captains of cruise OMA0801 Fish Resources Assessment Survey of the Arabian Sea Coast of Oman, Chris Carey and John Baxter, and the crew. Special thanks are extended to the voyage leader, Neil Bagley, and the rest of the scientific staff from NIWA.

Figure 1 was generously supplied to the authors by Lubna Al-Kharusi.

Earlier drafts of the manuscript were reviewed by Johan Groeneveld, N. Jayabalan, and Lubna AlKharusi (Marine Science and Fisheries Centre).

\section{References}

Abdallah, M. 2002. Length-weight relationship of fishes caught by trawl off Alexandria, Egypt. Naga, 25(1):19-20.

Abdurahiman, K.P., T. Harishnayak, P.U. Zacharia, and K.S. Mohamed. 2004. Length-weight relationship of commercially important marine fishes and shellfishes of the southern coast of Karnataka, India. Naga, 27(1\&2):9-14.

Akyol, O., H.T. Kinacigíl, and R. Şevík. 2007. Longline fishery and length-weight relationships for selected fish species in Gökova Bay (Aegean Sea, Turkey). International Journal of Natural and Engineering Sciences, 1:1-4.
Al-Abdessalaam, T.Z.S. 1995. Marine Species of the Sultanate of Oman. An Identification Guide. Ministry of Agriculture and Fisheries, Sultanate of Oman. Muscat. 412pp.

Al-Mamry, J.M.A. 2006. Biology and Fisheries Management of Argyrops spinifer and Lethrinus nebulosus in the Arabian Sea. School of Ocean Sciences, University of Wales. Bangor, Wales. $\mathrm{x}+$ 421pp.

Al-Nahdi, A., E. Al-Rasadi, H. Al-Waili, and J. AlMamry. 200x. Biology and stock assessment of Largehead hairtail Trichiurus lepturus from the Arabian Sea. Agriculture and Marine Science. $\mathrm{x}(\mathrm{x}): \mathrm{xx}-\mathrm{xx}$.

Al-Waili, H., A. Al-Marzouqi, M. Al-Boloshi, and I. Anbory. 200xa. Biology and stock assessment of mullet Crenimugil crenilabis from the Arabian Sea. Agriculture and Marine Science. $\mathrm{x}(\mathrm{x}): \mathrm{xx}-\mathrm{xx}$.

Al-Waili, H., A. Al-Marzouqi, A. Al-Nahdi, W. AlAmry, and B. Sadeq. 200xb. Biology and stock assessment of Geelbeck croaker Atractoscion aequidens from the Arabian Sea. Agriculture and Marine Science. $\mathrm{x}(\mathrm{x}): \mathrm{xx}-\mathrm{xx}$.

Anonymous. 2004. Fisheries Statistics Book 2003. Directorate General of Planning \& Investment Promotion, Statistics \& Information Department, Ministry of Agriculture and Fisheries. Muscat, Sultanate of Oman. 240pp.

Bernardes, R.A. and C.L.D.B. Rossi-Wongtschowski. 2000. Length-weight relationship of small pelagic fish species of the southeast and south Brazilian exclusive economic zone. Naga, 23(4):30-32.

Can, M.F., N. Başusta, and M. Çekíç. 2002. Weightlength relationships for selected fish species of the small-scale fisheries off the south coast of Ískenderun Bay. Turkish Journal of Veterinary and Animal Sciences, 26:1181-1183.

Carpenter, K.E., F. Krupp, D.A. Jones, and U. Zajonz. 1997. FAO Species Identification Field Guide for Fishery Purposes. The Living Marine Resources of Kuwait, Eastern Saudi Arabia, Bahrain, Qatar, and the United Arab Emirates. FAO. Rome. viii, 293pp +17 plates.

Compagno, L.J.V. 2001. Sharks of the World. An Annotated and Illustrated Catalogue of Shark Species Known to Date. Volume 2. Bullhead, Mackerel and Carpet sharks (Heterodontiformes, Lamniformes and Orectolobiformes). FAO Species 
Catalogue for Fishery Purposes. No. 1, Vol. 2. Rome. 269pp.

Frota, L.O., P.A.S. Costa, and A.C. Braga. 2004. Length-weight relationships of marine fishes from the central Brazilian coast. Naga, 27(1\&2):20-26.

Gonzales, B.J., H.P. Palla, and H. Mishina. 2000. Length-weight relationship of five serranids from Palawan Island, Philippines. Naga, 23(3):26-28.

Henderson, A.C., H.S. Al-Oufi, and J. McIlwain. 2007. Survey, Status and Utilisation of the Elasmobranch Fisheries Resources of the Sultanate of Oman. Final Report. Department of Marine Science and Fisheries, College of Agriculture and Marine Science, Sultan Qaboos University Muscat, Sultanate of Oman. vi + 134pp.

Human, B.A. 2006. Size-corrected shape variation analysis and quantitative species discrimination in a morphologically conservative catshark genus, Poroderma Smith, 1837 (Chondrichthyes: Carcharhiniformes: Scyliorhinidae). African Natural History, 2:1-15.

Human, B.A. 2007. Report on the F.V. Al-Mustaqila I Oman Cruise \#3. $4^{\text {th }}-24^{\text {th }}$ March, 2007. Unpublished Report for the Ministry of Agriculture and Fisheries. Muscat, Sultanate of Oman. May 2007. vii + 71pp.

Johanneson, K.A. 1991. Assessment of Major Marine Stocks of Demersal, Small Pelagic and Mesopelagic Species. $R / V$ Rastrelliger Acoustic and Trawling Survey Results. November 1989 - November 1990. FAO Rome. xiii, 77pp + appendices.

Mallicoate, D.L. and R.H. Parrish. 1981. Seasonal growth patterns of California stocks of northern anchovy, Engraulis mordax, pacific mackerel, Scomber japonicus, and jack mackerel, Trachurus symmetricus. California Cooperative Oceanic Fisheries Investigations Report, 22:69-81.

McClure, R.E. 1987. The Fisheries of the Sultanate of Oman. Annual Report 1986. RDA Contribution \#11-87. Ministry of Agriculture and Fisheries Muscat, Sultanate of Oman. iii + 30pp.

McIlwain, J, G.V. Hermosa, M. Claereboudt, H.S. Al-Oufi, and M. Al-Awi. 2006. Spawning and reproductive patterns of six exploited finfish species from the Arabian Sea, Sultanate of Oman. Journal of Applied Ichthyology, 22(2):167-176.
Morato, T., P. Afonso, P. Lourinho, J.P. Barreiros, R.S. Santos, and R.D.M. Nash. 2001. Length-weight relationships for 21 coastal fish species of the Azores, north-eastern Atlantic. Fisheries Research 50:297-302.

Muto, E.Y., L.S.H. Soares, and C.L.D.B. RossiWongtschowshi. 2000. Length-weight relationship of marine fish species of São Sebastião system, São Paulo, southeastern Brazil. Naga, 23(4):27-29.

Randall, J.E. 1995. Coastal Fishes of Oman. Crawford House Publishing Pty Ltd. Bathurst, New South Wales, Australia. 439pp.

Sahayak, S. 2005. Length weight relationship of Sufflamen fraenatus (Latreille, 1804) and Zenodon niger (Ruppell, 1835). Indian Journal of Fisheries, 52(3):357-360.

Santos, M.N., M.B. Gaspar, P. Vasconcelos, and C.C. Monteiro. 2002. Weight-length relationships for 50 selected fish species of the Algarve coast (southern Portugal). Fisheries Research, 59:289-295.

Sheridan, P.F., D.L. Trimm, and B.M. Baker. 1984. Reproduction and food habits of seven species of northern Gulf of Mexico fishes. Contributions in Marine Scienc, 27:175-204.

Smith, M.M. and P.C. Heemstra. 1986. Smiths' Sea Fishes. Macmillan South Africa (Publishers) (Pty) Ltd. Johannesburg. xx $+1047 \mathrm{pp}$.

Strømme, T. 1986. Pelagic and Demersal Fish Resources of Oman - Results of $R / V$ Dr. Fridtjof Nansen Surveys in Oman, 1983-1984. UNDP/ FAO Programme GLO/82/001. Institute of Marine Research Bergen, Norway. 123pp.

Valinassab, T., R. Daryanabard, R. Dehghani, and G.J. Pierce. 2006. Abundance of demersal fish resources in the Persian Gulf and Oman Sea. Journal of the Marine Biological Association, United Kingdom, 86:1455-1462.

Wigley, S.E., H.M. McBride, and N.J. McHugh. 2003. Length-weight relationships for 74 fish species collected during NEFSC research vessel bottom trawl surveys, 1992-99. Woods Hole Laboratory Massachusetts, United States of America. vi $+28 p$. 